\title{
GRIMINAL PROCEDURE: PROBABLE CAUSE PREREQUISITE TO AN EXTRADITION ARREST
}

IN Kirkland v. Preston ${ }^{1}$ the United States Court of Appeals for the District of Columbia Circuit announced that an extradition affidavit under section 1 of the Fugitives From Justice Act ${ }^{2}$ will not succeed in charging a crime unless it alleges facts sufficient to satisfy the fourth amendment probable cause requirement for arrest. Pursuant to its request for the extradition of appellants Kirkland and Smith, Florida submitted to the District of Columbia an arrest warrant, the required sworn affidavit putatively charging a crime, and a certificate of authenticity initialled by its Governor. The affidavit essentially set out Florida's second degree arson statute, and included in appropriate places appellants' names and the date and location of the alleged misconduct. At the extradition hearing, appellants argued that the affidavit upon which the arrest warrant was based failed to state probable cause for arrest; but the presiding officer refused to examine the issue, concluding that appellants were substantially charged and should be turned over to Florida for trial. ${ }^{3}$ Appellants' petition for a writ of habeas corpus was denied by the district court. ${ }^{4}$ Subsequently, the Court of Appeals for the District of Columbia Circuit ordered the writ unless Florida supplied a fourth amendment probable cause basis for arrest within two weeks-which it did not do. ${ }^{5}$

The procedure for effecting interstate rendition of accused criminals, broadly delineated in the Constitution, ${ }^{6}$ was particularized by Congress in 1793. 7 The current provision, essentially a codification of its 1793 forerunner, provides that in order to effect interstate extradition, the executive authority of a demanding state should certify and send to the executive of the asylum state either an indictment found or an affidavit sworn before a magistrate, charging the

\footnotetext{
1385 F.2d 670 (D.C. Cir. 1967).

218 U.S.C. $\$ 3182$ (1964).

3385 F.2d at 673. See also D.C. Code ANN. $\$ 23.401$ (a) (1961) (Chief Judge of district court appointed as extradition "executive").

4385 F.2d at 673 .

sId.

- U.S. Const. art. 1V, § 2.

' Act of February 12, 1793, ch. 7, $\$ 1,1$ Stat. 302; see Kentucky v. Dennison, 65 U.S. (24 How.) 66, 104 (1860).
} 
alleged fugitive with a crime. ${ }^{8}$ Among the objectives of the constitutional and federal statutory guidelines for extradition is facilitation of the safe and prompt return of accused persons to the state where they are criminally charged. ${ }^{9}$ Responding to this purpose, the judiciary has generally upheld state legislation which allows extradition upon less exacting terms than those set forth by the federal statute. ${ }^{10}$ Legislation demanding that certain state conditions be met in addition to the federal requirements has not, however, been sanctioned. ${ }^{11}$ Nonetheless, comity among the states is not the sole basis for the constitutional and federal statutory extradition provisions. A countervailing purpose-protection of the individual against spurious and indiscriminate charges-is also fundamental to the extradition scheme. ${ }^{12}$ Thus an accused has been guaranteed the right to test the validity of his extradition arrest and the substantiality of the charge against him by application for a writ of habeas corpus in the courts of the asylum state. ${ }^{13}$

The tension between the divergent underlying policies has led courts along two sometimes separate and conflicting paths in their review of extradition proceedings through habeas corpus petitions.

${ }^{8}$ Fugitives From Justice Act $\$ 1,18$ U.S.C. $\$ 3182$ (1964).

- E.g., Sweeney v. Woodall, 344 U.S. 86, 89-90 (1952); Biddinger v. Comm'r, 245 U.S. 128, 132-33 (1917); Appleyard v. Massachusetts, 203 U.S. 222, 227 (1906); Ex parte Morgan, 78 F. Supp. 756, 757 (S.D. Cal. 1948), aff'd sub nom. Morgan v. Horrall, 175 F.2d 404 (9th Cir.), cert. denied, 338 U.S. 827 (1949); Dudley v. Corbett, 46 Misc. 2d 205, 208, 259 N.Y.S.2d 572, 576 (Sup. Ct. 1965).

${ }^{10}$ E.g., Ex parte Morgan, 78 F. Supp. 756 (S.D. Cal. 1948), aff'd sub nom. Morgan v. Horrall, 175 F.2d 404 (9th Cir.), cert. denied, 338 U.S. 827 (1949) (extradition allowed although accused not in demanding state when crime committed); Gulley v. Apple, 213 Ark. 350, 210 S.W.2d 514 (1948) (out-of-state parolees required to waive any right to extradition proceedings); In re Davis, 68 Cal. App. 2d 798, 158 P.2d 36 (1945) (extradition based on an information allowed); People ex rel. Matochik v. Baker, 306 N.Y. 32, 114 N.E.2d 194 (1953) (same); Ex parte Peairs, 162 Tex. Crim. 243, 283 S.W.2d 755 (1955) (same).

${ }^{11}$ E.g., Ex parte Riccardi, 68 Ariz. 180, 203 P.2d 627 (1949) (statute required a copy of any warrant issued before extradition); People ex rel. Carr v. Murray, 35711 . 326, 192 N.E. 198 (1934) (evidence of good faith by demanding state required); In re Sanders, 31 N.E.2d 246 (Ohio App. 1937) (a statement of the reputation of the accused required).

${ }^{13}$ See, e.g., Johnson v. Matthews, 182 F.2d 677, 685 (D.C. Cir.) (Bazelon, J., dissenting), cert. denied, 340 U.S. 828 (1950); United States ex rel. McCline v. Meyering, 75 F.2d 716, 717 (7th Cir. 1934); Henry v. McArthur, 122 Colo. 474, 479, 223 P.2d 621, 623 (1950). See also J.B. Moore, Extradition \$532, at 842 (1891). See generally Comment, Extradition Habeas Corpus, 74 YALE L.J. 78 (1964); Note, 73 Y ALE L.J. 1098, $1104-05$ nn.30 \& 31 (1964).

${ }^{18}$ See, e.g., South Carolina v. Bailey, 289 U.S. 412, 419-22 (1933); Roberts v. Reilly, 116 U.S. 80, 95 (1885); cf. Smith v. Idaho, 373 F.2d 149, 156 (9th Cir. 1967) (new conflicting evidence not sufficient basis for release in such proceeding). 
Prompted by comity, many jurisdictions presume the propriety of the demanding state's request, ${ }^{14}$ and indicate that the accused bears the burden of proving that he is not a fugitive or is improperly charged with a crime. ${ }^{15}$ In other jurisdictions the sufficiency of the charging instrument, particularly an affidavit, ${ }^{16}$ has not been so readily accepted; and these courts, placing a greater emphasis on safeguarding the interests of the alleged fugitive, have subjected affidavits to closer scrutiny. ${ }^{17}$ Even before the Supreme Court ruled that the federal view of probable cause prescribed by the fourth amendment is applicable to state arrests, ${ }^{18}$ some jurisdictions required demanding affidavits to show probable cause for extradition arrests, ${ }^{10}$ though precise federal standards were not always employed. Now, as the Kirkland court noted, the fourth amendment standard is the "minimal and uniform requirement of a valid arrest."20

In Kirkland the District of Columbia Circuit affirmed that the apprehension of an accused by an asylum state for extradition is clearly a criminal arrest, and that the extradition clause of the Constitution does not conflict with any guaranteed constitutional rights. In light of these observations, the court reasoned that the fourth amendment probable cause requirement should apply equally to all arrests including those made to facilitate extradition. ${ }^{21}$ The court also recognized that the disadvantage endured by an individual extradited to another state without probable cause was particularly siguificant in light of the slight burden placed upon a demanding state required to include sufficient facts in its extradition affidavit to provide justification for arrest. ${ }^{22}$ The Kirkland court concluded

\footnotetext{
14 See, e.g., United States ex rel. Vitiello v. Flood, 374 F.2d 554, 557 (2d Cir. 1967); In re Tucker, 384 P.2d 413, 416 (Okla. Crim. 1963); Commonwealth ex rel. Raucci v. Price, 409 Pa. 90, 100.01, 185 A.2d 523, 528 (1962).

${ }^{15}$ See, e.g., United States ex rel. Vitiello v. Flood, 374 F.2d 554, 557 (2d Cir. 1967); In re Tucker, 384 P.2d 413, 416 (Okla. Crim. 1963).

${ }^{10}$ E.g., Henry v. McArthur, 122 Colo. 474, 479, 223 P.2d 621, 624 (1950) (affidavit alleging probable cause must be more exacting than indictment); People ex rel. de Martini v. McLaughlin, 243 N.Y. 417, 419, 153 N.E. 853, 854 (1926) (same).

${ }^{17}$ E.g., United States ex rel. McCline v. Meyering, 75 F.2d 716 (7th Cir. 1934); Raftery ex rel. Huie Fong v. Bligh, 55 F.2d 189 (1st Cir. 1932); Henry v. McArthur, 122 Colo. 474, 223 P.2d 621 (1950); People ex rel. de Martini v. McLaughlin, 243 N.Y. 417, 153 N.E. 853 (1926).

${ }^{28}$ Beck v. Ohio, 379 U.S. 89 (1964); Ker v. California, 374 U.S. 23 (1963).

${ }^{10}$ E.g., United States ex rel. McCline v. Meyering, 75 F.2d 716 (7th Cir. 1934);

Raftery ex rel. Huie Fong v Bligh, 55 F.2d 189 (1st Cir. 1932).

20385 F.2d at 674 .

21 Id. at 676.

$22 I d$. at 676-77.
} 
that Florida's affidavit plainly lacked the requisite basis, since the affidavit failed to identify the sources of its information and was framed in conclusory terms, mirroring the wording of the Florida criminal statute allegedly violated by the accused.

Kirkland ignores neither of the dual policies underlying interstate rendition. ${ }^{23}$ By demanding that an affidavit set forth facts sufficient to satisfy fourth amendment requirements, the District of Columbia Circuit has assured protection of the due process interests of persons demanded for extradition. On the other hand, since Florida, as demanding state, was given an opportunity to correct its defective affidavit and gain custody of the alleged fugitive, ${ }^{24}$ there is a tacit recognition of comity that should not be overlooked by courts purporting to follow Kirkland. Another widely recognized manifestation of the comity basis for extradition-the presumption of the validity of the charging instrument sent by a demanding state ${ }^{25}$ is not aborted by Kirkland's imposition of fourth amendment standards. While this supposition should not exempt an asylum state from constitutional requirements, in a closer case than Kirkland, where the facts supplied by the demanding affidavit did not obviously fall short of fourth amendment probable cause, this presumption could tip the scales toward acceptance of the sufficiency of the cause for the extradition arrest.

\footnotetext{
${ }^{33}$ See notes 9, 12 supra and accompanying text.

24 See note 5 supra and accompanying text.

${ }^{25}$ See note 14 supra and accompanying text.
} 